\title{
TOWARD DEFINING POLICY FRAMEWORK FOR LARGE-SCALE RETAIL IMPACT ADDRESSING IN SERBIA
}

\author{
UDC 339.33(497.11)
}

\author{
Milica Maksić \\ Institute of Urban Planning City of Niš, Niš, Serbia
}

\begin{abstract}
The main objective of this paper was to research how policy framework in Serbia could be improved to address impacts of large-scale retail development. The first step of the research included identifying economical, social and environmental impacts of large-scale retail construction through the review of literature. The second step of the research included the analysis of different type of procedures for retail impact addressing, applied in developed European countries. Finally, policy framework in Serbia was analyzed and recommendations for its improvement are given in accordance with the experiences of European countries.
\end{abstract}

Key words: large-scale retail, impact, addressing, policy, Serbia

\section{INTRODUCTION}

At the end of the twentieth century, there have been significant changes in the trade sector. Merging trade is one of the most important effects of these changes. Large retail formats have brought changes in consumer habits, changes in the role of urban centers, the directions of cities development.

In developed European countries, changes in retail sector and the introduction of large retail formats started in the nineteen-seventies, at the time of transition from industrial to postindustrial society, in context of a range of socioeconomic trends (population migration from cities to rural areas, increase in the number of cars, etc.). Changes in the structure of retail followed changes in the location requirements. Because of high land prices in centers and inaccessibility of central city locations, investors sought for locations outside the city centers, along the main roads. Numerous studies have been carried out in European countries to analyze the effects of retail development.

To reduce the negative effects of large-scale retail construction, and to limit and direct this phenomenon, European states formulated plans and regulations on various levels of spatial organization in the period of several decades. This regulation refers to preservation

Received February 24, 2016 / Accepted May 24, 2017

Corresponding author: Milica Maksić

Institute of Urban Planning City of Niš, 18000 Niš, Serbia

E-mail: mmaxic@gmail.com 
of central parts of cities, small retail preservation, reduction of traffic, etc. The experiences of European countries can be very instructive for Serbia to become aware of the consequences of inadequate large stores locating and to prepare state intervention to adequately respond to the expected pressure of investment in this area.

Introduction of large-scale retail in post-socialist countries happened three decades later, in specific economical and political environment. In Central and East Europe, in a sense, public and institutional support for large-scale retail spread has been even greater than in West Europe [1]. Many states encouraged programs of development with aim of attracting investors, but these policies encouraged urban sprawl, locating many of the newly established enterprise zones in suburban and ex-urban rings, where the land is considerably cheaper and easier to integrate [36].

There is diversity in the way new large-scale retail shape urban environment in postsocialist cities. The suburbanization of retail facilities has completely reshaped the pattern of commuting for shopping in Prague and a large share of shopping now takes place in edge-of-town and suburban shopping areas [26]. On the contrary to Prague, most of the large-scale retail in the city of Poznan in Poland are located within city limits and tend to concentrate around housing estates and in downtown areas, and are merely three cases of location outside city limits of Poznan in Poland [16]. In Budapest, the majority of new hypermarkets, cash and carry, do-it-yourself facilities chose their locations on the outskirts and in the metropolitan belt of the city along the motorways and some main axial roads, while the most largest shopping centres are situated at the relatively narrow densely built inner ring of Pest, in the transitional zone where they rely on both the high population concentration of the inner city and on the demand of outer districts [17].

Retail development happened in former Yugoslavian republics as well. In Ljubljana most retail expansion has taken place in the form of suburban shopping centres, causing structural changes by reducing the actively used retail space in the city centre and through the rapid disappearance of small dispersed stores in residential areas [7]. In Zagreb a lot of shopping malls are built in the city centre and on the outskirts, always accompanied by underground parking garages [38].

The paper is structured in the following way. First, economic, social and environmental impacts of retail construction are identified. The second part of the research consists of identifying different procedures for retail impact addressing in European countries. The final part of the research consists of analysis of policy framework in Serbia and its possible improvement to include retail impact addressing.

\section{THE IMPACTS OF LARGE-SCALE RETAIL CONSTRUCTION}

There are generally three types of impacts of retail development debated in literature: economic, social and environmental impacts. Economic impacts relate to changes in retail turnover or trading patterns, as well as adverse employment effects of new retail developments [10]. For example, Rebernik and Jakovčić concluded that opening of shopping centres in Ljubljana have had a strong impact on the business of retail outlets in the city centre but this topic deserves further research [31]. In that sense, large-scale retail building can even affect neighbouring settlements. The research of Robertson and Fennell, which examined the economic impacts of four regional shopping centres in the UK, has shown that their opening had some impact on adjoining centres in the period after being 
opened, but that such impacts were generally short-lived and in some cases stimulated new investment in the affected centres, while a few smaller centres were affected [34]. The findings regarding both the local and regional impact of Newcastle's Eldon Square Shopping Centre suggest that new shopping schemes have far less adverse consequences on existing patterns of trade then ensue from similar-sized developments located on the outskirts of towns [3].

Social impacts of retail development reflect in demographic changes and changes in customers behavior, changes in the social role of urban centers, the consequences of new forms of commercial developments on the customer base, as well as questions that certain sites are not available to all buyers. Equity aspects are concerned partly with the loss of retailing from traditional centres, and the impact of this on those who rely particularly on these shopping opportunities [14]. Those who do not own cars have become polarized as a disadvantaged groups whose poor mobility constrains their access to urban facilities [4]. Decentralization of retailing implied loss of social involvement in the wider community [13]. For example, recently built suburban shopping centres have shifted part of the inhabitants' daily activities to the suburban zone of the Prague metropolitan area [26].

Already in 1970s, researches have shown that the commercial viability of inner-city shopping street is highly influenced by pedestrian movement and that the impact of new retail development is closely related to the location patterns of magnet stores and the distribution of the transport termini [39]. The research of the relationship between shopping centers and shopping streets of Ozuduru et al. on the case on city of Ankara reveals that: shopping centers are used by consumers from all districts, in particular, from suburban districts, and shopping streets are mainly used by consumers living in inner city districts; the consumer profiles of shopping centers and shopping streets are distinctive in terms of age, occupation and education; shopping centers are usually preferred by car owners, which encourages development of new shopping centers at the urban fringe; shopping centers and shopping streets are preferred for similar purposes, and shopping streets, in particular, are preferred for entertainment [29]. The results of the survey of Reimers and Clulow show that consumers regard spatial convenience as important and believe that malls are superior in providing it in relation to shopping strip [32].

Third group of impacts are environmental effects of new large-scale retail development. Large retail stores use large areas of land for the sales area and the parking space. Many unbuilt green areas are used for large stores construction ("greenfield" site). In visual terms, these stores perform great pressure on the environment.

Large retail stores are large traffic generators and as a consequence, air pollution. A particular problem is their positioning outside the city center, along the main traffic roads, when it leads to "strip" spread of cities and increased expenses due to infrastructure development.

Decentralized retailing has been accused of encouraging private car travel at the expense of walking, cycling and public transport trips, and increasing overall length of shopping trips by car. The counter argument, that further development of off-centre retailing is desirable because it reduces average trip length, has also been debated [14]. The research of Popa, Raicu and Rosca of streets network congestion in the Bucharest case showed that if we considered the decision problem of a single hypermarket location, the results of the model indicated in short that the users' cost and the car traffic congestion at the entire network level increased with respect to the distance from the city centre [30]. According to Garb, environmental characteristics of malls can be improved 
by locating them on public transport routes in central locations: about a quarter of the trips can then come by transit and average travel distances could be almost halved [12].

The physical appearance of off-centre retailing has been much criticized [14]. By introducing large-scale retail formats, large physical structure is inserted into smaller physical structure, in the most cases housing areas.

In some cases local governments used retail investments to regenerate certain areas. Cummins et al. researched the effects of hypermarket intervention which was developed as part of a regeneration initiative in a deprived and "under-served" area of Springburn, Glasgow. In terms of the built environment the effects of this large scale retail initiative have been positive in the three years after opening, providing not just improved food provision, but improved food choice, increased physical and economic accessibility and wider regeneration effects [8]. Development of the West Quay retail scheme in the city of Southampton have been overwhelmingly positive for the city and that, as such, the Southampton example supports the case for retail-led urban regeneration [19]. Cities like Southampton pioneering the link between retail and urban regeneration as a central component of a strategy focused on the development and promotion of successful places [20].

Therefore, the impacts of large-scale retail construction can be summarized as:

- Positive effects on the economy: greater competition, diversity of supply, lower prices, income from rents and fees, enlargement of commercial networks, new jobs through direct employment opportunities in trade, as well as indirect jobs by providing goods and services for new stores or new jobs generated during construction. Positive social impacts refer to new retail forms (shopping centres, retail parks) as new public spaces;

- Negative economic impacts refer to small businesses, trade costs and employment. Opening of a new large trade leads to weakening of the position of small independent retailers and small businesses. Negative social impacts refer to loss of retailing from traditional centres, loss of social role of urban centers, equity aspects and questions that certain sites are not available to all buyers (elderly, people with special needs, families without cars). Negative environmental effects are especially expressed as traffic problems, the ones due to increased car use, the use of large areas of land for sell area and parking space.

\section{PROCEDURES FOR RETAIL IMPACT ADDRESSING}

There is great variety of procedures applied in European countries in order to direct large-scale retail impacts. First group are procedures developed as part of spatial planning system. A very important issue in retail development is whether the size of the retail formats should be limited by the state, or in some cases, by special procedures (or at special locations) larger retail development should be permitted. For example, Ireland, according to Retail Planning Guidelines for Planning Authorities, limits the surface of retail: $3,000 \mathrm{~m}^{2}$ for grocery stores (for Greater Dublin area $3.500 \mathrm{~m}^{2}$ ), $6.000 \mathrm{~m}^{2}$ for retail warehouse, and $15.000 \mathrm{~m}^{2}$ for retail parks [33]. Guidelines allow retail warehouse stores to exceed $6.000 \mathrm{~m}^{2}$, but only in areas of the Plan of integrated areas under the Urban Renewal Act of National Spatial Strategy of 1998. 
In Germany, according to Federal Land Utilisation Ordinance (Baunutzungsverordnung), if the area of retail shop exceeds $1.200 \mathrm{~m}^{2}$, the provisions of zoning, by which retail construction is permitted only in the central areas of major cities or in special areas, are applied [2]. In the UK, sequential approach to site selection is defined by the national document Planning Policy Statement 6: Planning for Town Centres (PPS6), which gives priority for retail locating to existing centres. Locations are discussed in the following order:

- first, locations in appropriate existing centres where suitable sites or buildings for conversion are, or are likely to become, available within the development plan document period, taking account of an appropriate scale of development in relation to the role and function of the centre; and then

- edge-of-centre locations, with preference given to sites that are or will be well connected to the centre; and then

- out-of-centre sites, with preference given to sites which are or will be well served by a choice of means of transport and which are close to the centre and have a high likelihood of forming links with the centre [27].

We can conclude that there are differences in European countries about variety of questions. First, the limit of retail gross building area from which it affects the environment significantly, differs in European countries. Second, there is diversity in type of applied regulation (law, strategy, guidelines) and the level of the binding. Third, the approaches vary significantly between different countries (zoning, sequential approach, etc).

The second group of procedures belong to retail impacts assessment through the procedure of environmental impact assessment. European countries, in accordance with European Directives: the Directive on Environmental Impact Assessment (EIA Directive 85/337/EEC with amendments 97/11/EEC and 2003/35/EEC) and the Directive on Strategic Environmental Assessment (SEA Directive 2001/42/EC), are required to consider the impacts of certain construction projects (i.e. plans and programs) on the environment and thus incorporated this subject in their regulations. Limits in the retail size from where it significantly affects the environment vary considerably in developed European countries.

In Germany, mandatory environmental impact assessment is prescribed for projects that exceed a certain trade area. The Law on Environmental Impact Assessment (Gesetzüber die Umweltverträglichkeitsprüfung - UVPG) outlines that the environmental impact assessment of the construction of a shopping mall or any large-scale retail, for which local development plan was prepared for the existing outdoor area in terms of article 35 of the Federal Law on Construction, is required for projects exceeding $5.000 \mathrm{~m}^{2}$. For projects of minimum area of $1.200 \mathrm{~m}^{2}$ "screening" is compulsory process, in which the competent authorities would, according to the criteria in Annex 2 of Law on environmental impacts assessment, determine whether the building could have significant adverse impacts on the environment [11].

In accordance with the Directive on the assessment of environmental impacts in the Netherlands, shopping centers belong to the category of urban development projects, for which environmental impact assessment is not defined as mandatory. The process of screening is required if the area exceeds 100ha, or commercial space has more than $200.000 \mathrm{~m}^{2}[25]$.

In the UK, mandatory environmental impact assessment of large-scale retail construction is not defined. According to the Statutory Instruments 2011 no. 1824 The Town and Country Planning (Environmental Impact Assessment) 79 Regulations 2011), retail projects belong to 
urban development projects for which screening process is performed for minimum area of 0,5 ha [37].

Third group covers special procedures developed for accessing retail impacts. For example, in Belgium, according to the Law for the approval of commercial projects in 2004. (Loi relative à l'autorisation d'implantations commerciales, 2004), commercial projects should receive socio-economic permit. The law provides for three types of procedure: for small commercial projects whose sales area is between $400 \mathrm{~m}^{2}$ and $1,000 \mathrm{~m}^{2}$; large commercial area of more than $1,000 \mathrm{~m}^{2}$ and simplified procedures for projects of limited expansion and relocation of approved commercial projects. Socio-economic permit is issued in the first case by the mayor or a representative of his collegium (within 50 days), in the second the same with the expert consultation with the National Socio-Economic Commission (within 70 days) and in the third by the municipality [18].

In the UK, special procedure for accessing retail impact on transport is developed. The National document Planning Policy Statement 13: Transportation and land use defines the obligation of making travel plans, for construction projects which would most likely have remarkable effects on transport. These plans are submitted with the application for the planning permission, for building projects which are likely to have significant transport implications. The Statement indicates that these plans should be developed in consultations with local authorities and local transport providers. Travel plans can be made for the applicant, or be part of a wider initiative, organized by local authorities, including other constructions within the area (or part of the evaluation under the environment protection legislation). Under specific circumstances, travel plans may be binding: either through the conditions in planning permission, or through planning obligations [28].

\section{POLICY FRAMEWORK IN SERBIA}

Developing large-scale retail policies in post-socialist country, such as Serbia today, is a very fragile question. Apart transition toward market economy, many political factors influence large-scale retail building environment. When deciding on retail development, local governments see them as potential investments needed to be realized as quickly as possible, while the impacts on the environment are neglected.

The total modern retail stock in Serbia is estimated at $790,000 \mathrm{~m}^{2}$ in the beginning of 2016 [9]. Serbia disposes of $48 \mathrm{~m}^{2}$ per 1,000 residents, which ranks it at the very bottom of the European scale (average density GLA/1000 inhabitants $185 \mathrm{~m}^{2}$ ) [15]. According to global CBRE annual research ("How Global is the Business of Retail") on the presence of leading international brand retailers, in 2016 Serbia is positioned at place 52 on the global list, with $18 \%$ of share [6].

In Belgrade, as the capital city, modern shopping center stock is at the level of $255,000 \mathrm{~m}^{2}$ of GLA, or $153 \mathrm{~m}^{2}$ per 1000 inhabitants. The most common are western-style shopping centres $\left(104,650 \mathrm{~m}^{2}\right)$, followed by neighborhood mall $\left(50,100 \mathrm{~m}^{2}\right)$, secondary SC schemes $\left(36,100 \mathrm{~m}^{2}\right)$, department stores $\left(35,476 \mathrm{~m}^{2}\right)$ and finally retail parks $\left(27,000 \mathrm{~m}^{2}\right)$ [5].

In addition to Belgrade as the capital, a number of large stores has been built in large cities such as Novi Sad (Big Shopping Center, hypermarket centers Rodić, shopping center Mercator), Niš (shopping center Mercator, hypermarket Tempo, retail park Stop shop), Kragujevac (shopping center Plaza, hypermarket Tempo). 
With the introduction of modern shopping formats retail scheme and the use of existing retail space in Serbia has changed. Commercial spaces in Serbia built twenty or more years ago are now generally weak business [24].

Retail distribution in different cities in Serbia shows diversity. For example, in Belgrade in the period after 2000 most of large-scale retail has been built in the area of main city centre (Ušće shopping center, Delta city shopping center, Metro hypermarket) [35]. Unlike Belgrade, most modern retail formats in Niš are built in naselje Duvanište, within the urban structure, but on the boundaries of the city (Roda shopping center (ex Mercator); Dis hypermarket; Interex hypermarket; retail park Stop shop). There is an uneven distribution of large-scale retail formats in relation to the distribution of housing in Niš, because the ownership status of the land (land in public ownership) was a predominant factor in choosing locations for large-scale retail projects [21].

In chapter 3, we analyzed 3 types of procedures in European countries developed in order to direct large-scale retail impacts. First group are procedures developed as part of the spatial planning system. The research of large-scale retail policies regarding spatial planning system in Serbia can be found in Maksić [21, 22, 23].

In Serbia, there are no particular guidelines regarding large-scale retail development in spatial plans formulated at all levels of spatial organization (national, regional, local). By analyzing adopted regional spatial plans (Regional Spatial Plan for the municipalities of South Pomoravlje, The Regional Spatial Plan for the administrative districts of Nišava, Toplica and Pirot, Regional Spatial Plan of the Administrative Area of the City of Belgrade The Regional Spatial Plan for Zlatibor and Morava administrative districts, The Regional Spatial Plan for Timočka krajina, The Regional Spatial Plan for the Autonomous Province of Vojvodina), Maksić [22] concluded that none of these plans contains guidelines for the construction of large retail stores. Similar situation was found by Maksić [22] at the local level, where spatial plans of the units of local self-government do not develop guidelines for the construction of large retail stores.

Spatial plans do not connect retail structure with the network of settlements which they determine. Therefore, locations of large retail stores are determined by urban plans at the local level (general urban plans and plans of general regulation). Maksić [22], analyzing different general urban plans in Serbia, found great methodological diversity in defining purpose, location and construction criteria for large stores in general urban plans in Serbia. General urban plans in Serbia assign the locations of large retails stores along major transport corridors on the frontlines of the cities (in economic areas, within work areas), but also in commercial areas in urban centres [22].

Regardless of the fact that planning documents at all levels of spatial organization in Serbia govern the issue of transport, neither the issue of large-scale retail construction nor relation to transport and traffic issues (public transport assessment, traffic congestion, etc), is distinctly recognized in these planning documents [23]. As the investments are needed, local governments in Serbia don't have the practice of formulating transport and traffic studies, when issuing building permits for this type of objects.

Social inclusion of vulnerable groups as a theme is not present in planning documents which consider retail. Plans do not elaborate criteria for large-scale retail accessibility by public transport or by foot [23].

Regional impacts of large-scale retail are not estimated (neither impacts on neighboring municipalities nor impacts on neighboring settlements within the same administrative boundaries). Regional spatial plans which elaborate the networks of settlements on the 
level of region and spatial plan of units of local government which elaborate the networks of settlements on the level of unit of self-government do not consider the theme of largescale retail building, nor connect retail hierarchy with network of settlements. When building new large-scale retail, impacts of opening large-scale retail on existing retail are not estimated [23].

The second group of procedures analyzed in chapter 3 , belong to retail impacts assessment through the procedure of environmental impact assessment. Serbia, like European countries, in accordance with European Directives: the Directive on Environmental Impact Assessment (EIA Directive 85/337/EEC with amendments 97/11/EEC and 2003/35/EEC) and the Directive on Strategic Environmental Assessment (SEA Directive 2001/42/EC), is required to consider the impacts of certain construction projects (i.e. plans and programs) on the environment and thus incorporated this subject in their regulations.

Environmental impact assessment is not obligatory for retail projects in Serbia, regardless of their size. Retail projects belong to List II - a list of projects for which environmental impact assessment may be required. If the total usable area is between $1.000 \mathrm{~m}^{2}$ to $4.000 \mathrm{~m}^{2}$, potential impact of the construction is estimated, and if the total usable area is of $4.000 \mathrm{~m}^{2}$ or more, significant impact is estimated [40]. In practice, local governments use this article in order to implement retail projects, and do not access environmental impacts of this type of activity.

Third group covers special procedures developed for accessing retail impacts. There are no types of these procedures developed in Serbia for retail impact assessment.

\section{CONCLUSION AND RECOMMENDATIONS}

The analysis of institutional framework has shown a number of weaknesses in directing large-scale retail impacts in Serbia. Spatial plans at all levels of spatial organization do not elaborate policies for large-scale retail building in Serbia. Spatial plans, which determine network of settlements, do not connect retail structure with network of settlements, nor access the impact of large-scale retail construction on neighbouring settlements or neighbouring municipalities.

Horizontal policy coordination of large-scale retail policies with other sector policies is very weak. There is especially insufficient integration with transport policies. Plans do not elaborate criteria for large-scale retail accessibility by public transport or by foot.

The experiences of developed European countries show that, regardless of the fact that these countries have different legal and planning systems, as well as different models for planning large-retail stores, the problems of large-scale construction are addressed. These countries have tried to minimize the adverse economic, social and environmental effects produced by the construction and improper location of large retail development. The type of regulation, the type procedure, the allowed size of large-scale retail formats vary significantly in European countries.

Therefore, according to the European experiences, three types of procedures could be developed in Serbia. Here opportunities for developing each type of procedure in planning system in Serbia will be discussed.

First group are procedures developed as part of spatial planning system. This would imply incorporating the provisions on the construction of large stores at all levels of spatial organization. As spatial planning in Serbia is institutionalized at all levels of spatial 
organization (national, regional and local), this model is possible to be implemented in Serbia. Starting point in implementation of this model would be adoption of proper document (regulation, strategy) at the national level or definition of guidelines in the existing documents (Law on planning and construction, Spatial plan of the Republic of Serbia), which would define problems that plans at different levels of planning should elaborate in terms of largescale retail building. In this way, through the system of spatial planning these policies would be implemented down to the local planning level.

Second group are procedures which belong to retail impacts assessment through the procedure of environmental impact assessment. Environmental legislation in Serbia could be supplemented with detailed factors that should be analyzed during the environmental impacts assessment of large-scale retail development. Special topics derived from the European experiences include: traffic impact assessment, impact to network of settlements, to existing retail network, to vulnerable groups which do not have access to certain type of locations, impacts on land as a resource, visual impacts of new retail developments.

According to European experiences, developing special procedures for accessing retail impacts would imply introducing special laws/regulations for approving commercial projects, which would regulate special types of approvals for commercial projects (socioeconomic permit as in case of Belgium, or travel plans as in case of UK). This European experience could be implemented in Serbia as an obligation to local governments to formulate transport and traffic studies, when issuing building permits for large-scale retail objects.

As the retail is an area with expected investment pressure, Serbia should consider direction of large-scale retail construction through spatial planning system. Some of the suggestions are proposed in this paper on the basis of European experiences. In order to establish adequate measures for directing large-scale retail development, comprehensive and detailed analysis of relevant factors in the Serbian context is needed. Questions like the size of retail store which affects the environment considerably, the type of procedure, the type of instruments to be used should be determined in this process.

Building regulations in this area is very complex issue and requires multidisciplinary approach and detailed studies. Nevertheless, treating these issues in the policy framework of Serbia should be set as a priority, in order to accelerate the investment process and to reduce negative consequences of future large-scale retail development.

\section{REFERENCES}

1. Baar, K.: Land Use Legislation and Controls of Conflicts of Interest in Land Use Decision Making. Legislative Tools for Preserving Town Centres and Halting the Spread of Hypermarkets and Malls Outside of Cities, Institute for Transport and Development Policy (New York), 2002. [Online]. Available: http://www.itdp.org/SR/read_SR/Legislative_Tools.pdf, [11.12.2005.]

2. Baunutzungsverordnung (Verordnung über die bauliche Nutzung der Grundstücke) (1990). [Online]. Available: www.gesetze-im-internet.de/bundesrecht/baunvo/gesamt.pdf, [26.2.2011.]

3. Bennison, D.J. and Davies, R.L.: "The impact of town centre shopping schemes in Britain: Their impact on traditional retail environments", Progress in Planning, vol. 14, part 1, pp 1-104, 1980.

4. Bromley, R.D.F., Thomas, C.J.: "Retail Change: Retrospect and Prospect", In R.D.F. Bromley, C.J. Thomas, (eds.), Retail Change: Contemporary Issues. London: Routledge, 2003, pp. 2-9.

5. CBRE, Retail market stays in the investors' focus, [Online] Available: http://www.cbre.rs/assets/files/ reports/research/2016/Q1/belgrade-retail-q12016.pdf, [20.5.2017.]

6. CBRE, Serbia real estate today, 2016 [Online] Available: http://www.cbre.rs/assets/files/brochures/ serbia-real-estate-today-2016.pdf, [21.5.2017.] 
7. Cirman, A. and Pahor, M.: "Sustaining the Challenge from the Outskirts: City Centre Retail Viability in Ljubljana, Slovenia", Economic and Business Review, vol. 11, no 3, pp 217-231, 2009.

8. Cummins, A. Findlay, M. Petticrew, L. Sparks, "Healthy cities? The impact of food-retail led regeneration on food access, choice and retail structure", Built Environment, 31(4), 288-301, 2005.

9. Danos, Serbian market overview, 2016. [Online]. Available: http://www.danos.com.cy/data/frontImages/ pdf/Serbian_Market_Overview_1st_semester_2016.pdf, [21.5.2017.]

10. England, J. Retail Impact Assessment: A Guide to Best Practice, Rics Issues in Real Estate and Housing Series. London: Routledge, 2001.

11. Environmental Impact Assessment Act [Gesetz über die Umweltverträglichkeitsprüfung - UVPG], as published in the announcement of 5 September 2001 (BGB1. I p. 2350), [Online]. Available: http://faolex.fao.org/docs/pdf/ger36861E.pdf, [15.4.2014.]

12. Garb, Y.: The impact of retail deconcentration on travel to hypermarkets in Prague, Employment Deconcentration in European Metropolitan Areas, pp 235-264, 2007.

13. Guy, C.: Controlling New Retail Spaces: Planning for Retail Development: A Critical View of the British Experience. London: Routledge, 2007.

14. Guy, C. "Controlling New Retail Spaces: The Impress of Planning Policies in Western Europe", Urban Studies, vol. 35, no. 5-6, pp. 953-979, 1998.

15. Jones Lang LaSalle Offices, Serbian Retail Market Update, 2013. [Online]. Available: http://www.officefinder. rs/reports/pulse-update-on-retail-market-in-serbia-9.pdf, [1.7.2014.]

16. Kotus, J.: "Changes in the spatial structure of a large Polish city - The case of Poznań", Cities, vol 23, no 5, pp 364-381, 2006.

17. Locsmándi, G.: "Large-Scale Restructuring Processes in the Urban Space of Budapest", In R. Dalla Longa, (Ed.), Urban Models and Public-Private Partnership. Springer-Verlag Berlin Heidelberg, pp 131212, 2011.

18. Loi relative à l'autorisation d'implantations commerciales (2004). [Online]. Available: http://www.ejustice.just.fgov.be/cgi_loi/loi_a.pl?language=fr\&caller=list\&cn=2004081336\&la=f\&fromt $\mathrm{ab}=$ loi\&sql=dt=\%27loi $\% 27 \&$ tri $=\mathrm{dd}+\mathrm{as}+$ rank\&rech $=1 \&$ numero $=1$

19. Lowe, M.: "Rethinking Southampton and town centre futures", International Journal of Retail \& Distribution Management, vol 35, no 8, pp 639 - 646, 2007.

20. Lowe, M.: "The Regional Shopping Centre in the Inner City: A Study of Retail-led Urban Regeneration", Urban Studies, vol 42, no 3, pp 449-470, 2005.

21. Maksić, M. "Institutional obstacles in large-scale retail developments in the post-socialist period - A case study of Nis", Serbia, CITIES, vol. 55, pp. 113-121, 2016.

22. Maksić, M. "The Neo-Institutional Framework of Large-Scale Retail Spatial Policy Formulation Process in Serbia". Transylvanian Review of Administrative Sciences", Special Issue, pp. 90-110, 2014.

23. Maksić, M. Politike izgradnje velikih trgovina u Srbiji. Zadužbina Andrejević, 2014.

24. Market Network, Prodavnica prema kupcu, ali i trgovcu, 2011, [Online] Available: http://marketnetwork.rs/ retail/analiza-trgovine-srbija/43-trgovina-analiza-istrazivanje/ 946-prodavnica-prema-kupcu-ali-itrgovcu?showall=\&start=1, accessed on July 10, 2014.

25. Ministerie van Volkshuisvesting, Ruimtelijke Ordening en Milieubeheer Den Haag: The Texts of the Regulations on environmental impact assessment in the Netherlands, 2000, [Online]. Available: http://api.commissiemer.nl/docs/mer/diversen/os02-text.pdf, [15.4.2014.]

26. Novák, J. and Sýkora, L.: "A city in motion: Time-space activity and mobility patterns of suburban inhabitants and structuration of the spatial organization in the Prague Metropolitan Area", Geografiska Annaler: Series B, Human Geography, 89 (2), 147-168, 2007.

27. Office of the Deputy Prime Minister, Planning Policy Statement 6: Planning for Town Centres (PPS 6). London: TSO, 2005, [Online]. Available: http://www.communities.gov.uk/documents/planningandbuilding/ pdf/147399.pdf, [16.8.2009.]

28. Office of the Deputy Prime Minister, Planning Policy Statement 13: Transportation and Land Use (PPS 13). London: TSO. [Online]. Available: http://www.communities.gov.uk/documents/planningandbuilding/ pdf/147399.pdf, [1.5.2010.]

29. Ozuduru, B., Varol, C. and Yalciner Ercoskun, O.: "Do shopping centers abate the resilience, of shopping streets? The co-existence of both shopping venues in Ankara, Turkey", Cities, 2014, 36, 145-157.

30. Popa, M., Raicu, S. and Rosca, E.: "Decisions of hypermarkets location in dense urban area - effects on streets network congestion in the Bucharest case", Transport problems, 3 (4), pp 55-63, 2008.

31. Rebernik, D. and Jakovčić, M. "Development of Retail and Shopping Centres in Ljubljana", Razprave, 26, pp 5-26, 2006 
32. Reimers, V. and Clulow, V.: "Spatial convenience: Bridging the gap between shopping malls and shopping strips", International Journal of Retail \& Distribution Management, vol. 42, no. 10, pp. 864883, 2014.

33. Retail Planning, Guidelines for Planning Authorities, January 2005. Government of Ireland: Available: http://nss.ie/Retail_Planning_guidelines_Jan_05.pdf, [29.1.2016.]

34. Robertson, J. and Fennell, J. "The economic effects of regional shopping centres", Journal of Retail and Leisure Property, vol 6, no 2, pp 149-170, 2007.

35. Solujić, Z. Razvoj trgovinskih centara u Beogradu, predavanje u okviru Programa permanentnog usavršavanja Inženjerske komore Srbije, 29.06.2015., [Online]. Available: http://www.ingkomora.org.rs/ materijalpo/, [19.5.2017.]

36. Stanilov, K.: "Urban development policies in Central and Eastern Europe during the transition period and their impact on urban form". In K. Stanilov (Ed.). The Post-Socialist City: Urban Form and Space Transformations in Central and Eastern Europe after Socialism, Dordrecht: Springer, 2007.

37. Statutory Instruments 2011 no. 1824 The Town and Country Planning (Environmental Impact Assessment) Regulations 2011, [Online]. Available: http://www.legislation. gov.uk/uksi/2011/1824/pdfs/ uksi_20111824_en.pdf, [15.4.2014.]

38. Svirčić Gotovac, A. and Zlatar, J.: "Urban Processes in Zagreb. Residential and Commercial Developments", Hrvatski geografski glasnik, vol 77, no 1, pp 29-45, 2015.

39. Timmermans, H.: Retail Location and Consumer Spatial Choice Behavior, In A. Bailly, L. J. Gibson, (Eds.), Applied Geography: A World Perspective, Dordrecht: Kluwer Academic Publishers, 2004.

40. Uredba o utvrđivanju Liste projekata za koje je potrebna procena uticaja i Liste projekata za koje se može zahtevati procena uticaja ("Službeni glasnik RS", br. 84/05).

\section{KA DEFINISANJU OKVIRA POLITIKA ZA USMERAVANJE UTICAJA IZGRADNJE VELIKIH TRGOVINA U SRBIJI}

Osnovni cilj ovog rada je da istraži kako okvir politika u Srbiji može biti unapređen u cilju usmeravanja uticaja izgradnje velikih trgovina. Prvi korak istraživanja uključio je prepoznavanje mogućih ekonomskih, socijalnih $i$ uticaja izgradnje velikih trgovina na životnu sredinu, kroz pregled literature. Drugi korak istraživanja uključio je analizu različitih tipova procedura za usmeravanje uticaja izgradnje velikih trgovina, primenjenih u razvijenim evropskim državana. $U$ poslednjem koraku istraživanja analizira se okvir politika u Srbiji i daju preporuke za njegovo unapređenje u skladu sa iskustvima evropskih država.

Ključne reči: velike trgovine, uticaji, usmeravanje, politike, Srbija 